\title{
Guerrilla-style Defensive Architecture in Detroit: A Self-provisioned Security Strategy in a Neoliberal Space of Disinvestment
}

\author{
KIMBERLEY KINDER
}

\begin{abstract}
Self-provisioning has long been an important component of urban political economic processes. However, it has recently become a central feature of grassroots urban governance strategies as well. In tumultuous cities of the twenty-first century, with governments either unwilling or unable to effectively enforce zoning laws, police neighborhoods or manage infrastructure, some householders have begun performing these services instead. This article examines one subset of self-provisioning practices that has emerged in southwest Detroit where residents have taken steps to secure abandoned housing as a means of exerting social control over their living environment. These actions embody many contradictions and ethical dilemmas, and the intimate scale of action has left the structural production of disinvestment in places like Detroit largely unchecked. Nevertheless, these guerilla-style spatial interventions have emerged as critically important response strategies helping residents reduce their vulnerability and stabilize their blocks even as other nearby areas continue to experience decline.
\end{abstract}

Detroit is a quintessential urban space of disinvestment. Despite the immense affluence of its suburban surroundings, the city has been in decline for over six decades. This decline has many causes, including market restructuring, entrenched racism and neoliberal policymaking. The resulting municipal financial crisis and contraction of government services has left most neighborhoods bereft of adequate property management and emergency response services. Moreover, the stalwart efforts of philanthropies and community organizations have been unable to counter market disinvestment or replace lost services. In this context, spatial abandonment has become an overarching issue, both as a symbol of decay and as a source of danger. Empty residential structures in Detroit are plentiful and notorious as havens of drug dealing, scrapping and arson.

In response, many of the residents I interviewed in southwest Detroit devised strategies to thwart these trends. This article focuses on a subset of commonplace, indirect tactics that involved reshaping domestic architecture to restrict access to empty spaces as a means of exerting social control over the behaviors carried out in those spaces. For example, residents disguised vacant structures using window treatments, children's toys and holiday decorations to make empty houses look occupied. They planted flowers, trimmed hedges and painted facades to inscribe evidence of care onto buildings, which distinguished empty spaces from abandoned ones. They boarded 
properties and barricaded pathways to physically bar access to these spaces. In certain instances, residents dismantled housing to permanently eliminate the personal risks they bore when living next to vacant structures. These architectural interventions were stopgap measures that required ongoing attention and that were easily undone. Even so, interviewees firmly believed these strategies could keep social behavior in check, slow the spread of blight and protect them from bodily harm.

Although the history of Detroit's decline has followed its own twists and turns, residents in many US and European cities have shared a similar fate. The twentieth century ideological aspiration of centralized municipal governments providing universal services has faded. A neoliberal rhetoric of government austerity and market-based provisioning has taken its place. As a result, residents in dozens of large cities live without many basic services, and they do so with little chance of successfully rallying government support for reform through invocations of social justice. In Detroit, and countless underserved neighborhoods like it across the North Atlantic, many residents have little choice but to perform the work themselves that, in wealthier areas, ordinarily falls to municipal governments and their market partners.

The rich, ethnographic account of guerrilla-style defensive architecture that follows vividly recounts the everyday labor residents in southwest Detroit perform to try and keep their living environment safe and governed, at least in part. Their creativity can be wonderfully inspiring. However, rather than romanticizing this bootstrap urbanism as a model to emulate, it is perhaps best to interpret these narratives as cautionary tales. Their efforts illustrate the short-term actions people have taken when no other options seemed available, with the hope that other comprehensive solutions to disinvestment and security would eventually emerge.

\section{Resident responsibility and place making in neoliberal cities}

Preeminent urban theorist David Harvey (1989a; 1989b) analyzed fundamental shifts in city management practices over the past four decades. The mid-twentieth-century decline of industrialization as an engine for centralized and exponential urban growth reached a crisis point by the early 1970s. In the United States, investors turning to suburban and 'sunbelt' regions had been pulling money and jobs out of northeastern urban manufacturing operations for years (see also Beauregard, 2006). The ensuing economic collapses and municipal fiscal crises left many large cities and towns with falling credit scores and with insufficient resources to continue providing services to residents and businesses. From this crisis moment, new urban growth coalitions emerged, characterized by a shift away from managerial governments claiming responsibility for service provisioning and a shift towards entrepreneurial governance models with authorities subsidizing 'big business' through infrastructure investment and tax incentives while transferring service provisioning to newly created private entities.

These changes were fundamental to the rise of neoliberal government austerity in countless US and European cities. Several UK-based scholars have tracked this transformation internationally. Jamie Peck and Adam Tickell (2002), for instance, theorized the shift as a two-pronged process involving a rollback of collective, Keynesian, welfare institutions and a subsequent rollout of new state forms and social policies that disciplined and contained people dispossessed by the restructuring. Similarly, Stephen Graham and Simon Marvin (2001) traced the splintering effect these policy changes had on urban infrastructure management and service provisioning in many countries as private entities assumed piecemeal ownership of utility operations and, under the banner of efficiency, began using market logic rather than universal entitlement to guide service delivery decision making. In many cases, for instance as Karen Bakker (2003) documented with respect to municipal water supplies, this partial privatization resulted in price increases and lost services to the detriment of lower-income residents. 
Jason Hackworth (2007), who analyzed these dynamics as they unfolded in the United States, explained that investors and policymakers routinely exploited moments of municipal fiscal crises as opportunities to force the implementation of neoliberal reforms. New York City's near municipal bankruptcy in the mid 1970s was a landmark example. With municipal resources depleted and bond agencies threatening to downgrade the city's credit rating, officials yielded to investors' demands. In exchange for continued financial investment, city leaders cut social services and selectively privatized utility companies and social service facilities, making New York City a model of government austerity and public-private service provisioning for dozens of other US cities to follow. Detroit was no exception. In the early 1980s, Detroit officials responded aggressively to falling credit ratings by 'reigning in the city's finances, improving the perception of corruption, collecting taxes, and perusing economic development' (Hackworth, 2007: 38). However, in Detroit's case, whatever the dollars saved on social service cutbacks, bond agencies still downgraded the city's credit scores. They justified the decision based on the extremity of Detroit's ongoing decline which, as other scholars have shown, was in large part the result of racially motivated refusals to build metropolitan wide transportation infrastructure or establish regional resource sharing programs that mitigated decline in similarly distressed cities such as Philadelphia, Cleveland, Minneapolis and Chicago (Sugrue, 1996; Thomas, 1997).

The 2007 Great Recession elevated the municipality's financial distress to new levels and, in 2013, Detroit became the largest US city ever to file for bankruptcy (Associated Press, 2013; CNBC, 2013). Put another way, although lenders, investors and bond-rating agencies were willing to prevent other, equally distressed, larger cities from entering formal bankruptcy in exchange for government reforms, few investors or government officials demonstrated interest in negotiating with Detroit. This abstention was in no way a break with the doctrine of neoliberal urbanism. Rather, investors exercised their right to choose not to take over service provisioning in unprofitable contexts. From this history, it is clear that Detroit followed a locally contingent path relative to its peer cities in that the collapse of government service provisioning resulted in part from deliberate neoliberal reforms that nonetheless failed to attract new investment and in part from racial animosity that prevented suburban wealth from flowing across municipal boundaries. Even so, the end result of unaffordable or unavailable basic services in many residential neighborhoods had much in common with other underprivileged areas in 'successfully restructured' cities of government austerity elsewhere in the United States.

Within these well established neoliberalism debates, an emerging literature has begun analyzing the labor that marginalized residents are now expected to perform to secure basic services for their neighborhoods. Two recent works are especially relevant: Rebecca Dolhinow's (2010) study of water utility expansion in peri-urban Colonia settlements near the US-Mexico boarder and Vincanna Adams' (2013) analysis of residential reconstruction after Hurricane Katrina in New Orleans. In both instances, residents faced public-private consortiums whose profit mandates prevented them from providing basic services to disadvantaged areas. To overcome this dilemma, residents acted as volunteer community leaders and unpaid laborers, generating neighborhood support for development strategies and soliciting donations of time and money from neighbors and outside charities to cover the financial shortfalls investors would incur by servicing those areas. These studies build on previous work by Steve Herbert (2005) and Mary Pattillo (2008) on neoliberal strategies of 'off-loading' government functions not only onto private corporations and charities but also onto ill-equipped residents who were then expected to produce or shop for basic security, educational and recreational services on an individual basis.

The Colonia and post-Katrina case studies differ from Detroit in important ways. In the Colonia example, people took up residence in under-served areas with the expectation that services would be absent for a while but would gradually improve. In contrast, Detroit had been experiencing a half century of what Lauren Berlant (2011) in her work on public spheres and affect worlds might describe as a 'slow death' where the 
governance goal is to manage the wearing out of life rather than its reconstitution. Instead of anticipating future growth, by 2010, dominant city planning discussions used terms like 'shrinkage' and 'rightsizing' - with varying glosses of optimism - to describe Detroit's future trajectory (e.g. Gallagher, 2010). Instead of looking towards infrastructural expansion, the primary challenge in Detroit was to manage the decay of infrastructure that previous owners had discarded. Moreover, unlike the New Orleans scenario, Detroiters had to proceed without the benefit of emotional disaster narratives that stirred regional and national compassion to charitable action.

Despite these differences, this article demonstrates that many Detroit residents now find themselves in similar roles as their counterparts in New Orleans and the American Southwest. In the wake of government austerity, and given a marked lack of market interest in taking up the slack, some Detroiters have begun incorporating infrastructure management tasks into their daily routines. Their experiences, combined with those from New Orleans and the Colonias, highlight the need for a more comprehensive theory about the new role of resident labor in urban management paradigms. This article contributes to that discussion with an example of the work some Detroiters now perform to manage abandoned residential infrastructure to meet their neighborhoods' basic security needs.

In these endeavors, residents renegotiated the definitions and boundaries of public and private space. Theorists like Harvey (1989b; 2001 [1992]) and Peck and Tickell (2002) emphasized that neoliberal impulses to discipline the dispossessed, make cities compete for high-income jobs and use market logic to guide place making have radically transformed the nature of urban public space. The landmark reconstruction of Baltimore's Inner Harbor, for instance, involved extensive and costly infrastructure transformations, as well as the erection of new barriers preventing 'unwanted' people lower-income and often minority residents living nearby — from accessing these newly reinvented public spaces and disrupting the illusion of leisure and happiness that investors cultivated for their wealthier clientele. Other theorists including Mike Davis (1992), Don Mitchell (2003) and Stephen Graham (2011) likewise noted these privatization trends, a change most visibly manifest in the growing use of security cameras and private guards to patrol ostensibly public spaces and move marginalized people along. These practices also involved the increasing use of defensive architecture, an approach Oscar Newman (1973) popularized in his classical and controversial treatise on the use of physical design elements - such as low walls, paving patterns and decorative lights - to deter the general public from entering communal spaces in residential settings as a crime prevention measure. In the more recent literature, defensive architecture commonly took the form of segmented benches that prevented people from sleeping in public, low shrubbery that exposed occupants' behavior to passersby and fenced perimeters creating the illusion that public spaces were actually private.

Concomitant with those changes, Margaret Crawford (Chase et al., 2008), Jeffery Hou (2010) and Andrew Herscher (2012) analyzed an interrelated transition: the actions residents took to challenge and circumvent these spatial closures by provisionally appropriating 'residual' industrial and transportation infrastructure for public-like activities - such as street vending, homeless encampments, art installations and community gatherings - that were no longer tolerated in privatizing public spaces. Most scholars emphasized the utility of these spatial seizures in high-rent or highly policed contexts. Andrew Herscher's Detroit-based analysis, however, studied these dynamics in a context of urban disinvestment where widespread capital withdrawal effectively disconnected large tracks of land and infrastructure from formal market circuits, which inadvertently created opportunities for nonmarket actors to appropriate empty buildings and abandoned lots for communal, anticapitalist experimentation. In all these examples, resident uses of space eluded their officially envisioned functions, which again reflected the work residents performed in response to neoliberal governance strategies, this time by self-procuring collective gathering sites. 
Spatial reappropriation in Detroit, however, came with two significant caveats. First, empty structures abound in residential areas, and their association with criminal activity is well known. According to my research, insurgent interventions into the city's 'residual' spaces occasionally assumed socially conscionable forms in the eyes of neighbors. Far more often, however, neighbors saw these activities as unwanted and dangerous intrusions into their private home environments. However much residents may have relished the idea of a pop-up beer garden next door - and not all residents did many interviewees still expressed their preference to see new owner occupants moving in. Moreover, the small hope that a provisional reappropriator might contribute to neighborhood vitality often paled in comparison to the more likely statistical reality that the person seizing space was more likely to peddle narcotics than beer, that the structure being appropriated was more likely to be burned than turned into an art piece, and that the squatter occupant was thought more likely to steal electricity from neighbors than to mow the lawn and trim the hedges.

As a second caveat, vacant residential structures in Detroit functioned as an ambiguous space between the public and private realms. In 2010, nearly a quarter of Detroit's 350,000 housing units stood empty (Detroit Works Long Term Planning Steering Team, 2012: 98). As a result of tax foreclosure, many empty structures had become city-owned property. Regardless of ownership, houses and apartment buildings with absentee owners were the object of significant municipal attention in the form of code enforcement, police surveillance and demolition campaigns. Even so, given the city's cash-strapped state, municipal attempts to keep empty structures maintained and secured often failed. As a result, in interviewee responses, vacant structures functioned as near-public spaces that, due to their ambiguous status, were likely to be provisionally repurposed in dangerous ways.

As such, this article walks a delicate line. A person removing metal and appliances from empty houses for resale was, in a narrow sense, not so different from a person planting vegetable gardens in front of them. From an academic perspective, both people engaged in self-provisioning. Nevertheless, from a perspective of situated embeddedness, only one actor appeared ethical and democratically legitimate. The fear that drug dealers, scrappers and arsonists might seize empty buildings immediately adjacent to their homes prompted many interviewees to erect guerilla-style defensive architecture on and around those properties for exclusionary purposes. Therefore, unlike the accounts of art galleries, dance festivals, beer gardens and homeless encampments described elsewhere in the literature, the residents interviewed here made preemptive interventions in residual 'free spaces' not to liberate them from privatized, capitalist dictates but rather to keep formerly private venues from slipping closer into the public realm of potentially seize-able space.

\section{Research context and methods}

Disinvestment in Detroit is not unique, as evidenced by the nearly 130 cities, towns and villages that were dissolved nationwide between 2000 and 2010, as well as the 35 other counties, municipalities and municipal utility units that have also declared bankruptcy between 2010 and Detroit's filing in 2013 (Maher et al., 2012; Plumer, 2013). These official proceedings represent extreme cases of disinvestment in property markets, employment sectors and government services. Detroit is the largest city to be so fully engulfed by these trends, making it an especially apt place to see the affect that disinvestment has on the shifting role of residents as individual managers of collective urban affairs.

The broad brushstrokes of Detroit's decline are well known. Detroit was the fourth largest city in the United States from 1920 until 1950 with nearly two million residents at its industrial peak. It was renowned as the birthplace of Henry Ford's mass production 
assembly line, a powerful hub of labor union organizing and an influential center of black political activism (Georgakas and Surkin, 1998; Thompson, 2001; Dillard, 2007). However, the advent of the post-second world war urban growth paradigm based on suburbanization and consumerism undercut its national prominence. Detroit's suburbs continued to grow in population and wealth while, from the 1950s onwards, deindustrialization and racism spearheaded six decades of decline within the city limits (Sugrue, 1996). A string of city planning efforts proved insufficient to overcome the administrative inadequacies and racial biases spurring decline, let alone reverse job loss and population outflow (Thomas, 1997). By 2012, with 700,000 residents, Detroit had become the 19th largest US city and was perhaps best known as a place of high unemployment, concentrated poverty, racial isolation, decaying infrastructure and violent crime (Austin and Doerr, 2010; Binelli, 2012; LeDuff, 2013). Although minor public-private revitalization efforts had modest success in downtown and riverfront areas, most residents lived with chronically substandard public school systems, inadequate snow removal and street light services, and underfunded park and recreation amenities. Citywide, 79,725 vacant housing units covering 19 square miles of land stood empty and another 5 square miles of residential parcels no longer had any structure left standing at all (Davidson, 2012; Detroit Works Long Term Planning Steering Team, 2012).

The Springwells Village neighborhood in southwest Detroit mirrored the city's overall trajectory in many ways. Built over several decades in the early twentieth century, the neighborhood housed immigrants from Ireland, Germany and Eastern Europe alongside migrants from West Virginia and Kentucky. Some residents became doctors, tailors, butchers, grocers, barbers, dentists and optometrists. Even more found jobs in small metalworking plants, biding their time until their English was sufficient to get better paying jobs in the booming auto factories nearby. During interviews, longtime residents looking back — perhaps through rose-tinted glasses - remembered the mid-century neighborhood as a place with shops and families where people knew each other and upward mobility was common. They also remembered a turbulent period associated with industrial downsizing in the 1970s, leading to population loss, business failures, church closures, increased vacancy and renting, and growing gang and drug activity.

Some respondents described feeling a temporary reprieve in the 1990s and early 2000s as Hispanics from Texas, Mexico and other parts of Latin America arrived and opened restaurants, renovated houses and raised children, a common trend across southwest Detroit but an anomaly citywide. By 2010, about $72 \%$ of the 16,859 residents living in Springwells Village were of Hispanic or Latino descent, 21\% were white and 5\% were African American, in sharp contrast to Detroit overall which was $82 \%$ African American, 8\% white and 7\% Hispanic (Data Driven Detroit, 2012). Despite this demographic shift, the 2007 Great Recession spurred new rounds of abandonment. The number of vacant housing units in Springwells Village increased 132\% between 2000 and 2010. In that decade, 275 housing units were demolished and 753 housing units went vacant.

Several neighborhood characteristics made Springwells Village a suitable place to look for resident self-provisioning. First, vacancy rates and poverty levels in Springwells Village were nearly identical to citywide averages. By 2010, 20\% of the 6,429 housing units in Springwells Village were unoccupied, which nearly mirrored the 23\% vacancy rate citywide (Detroit Residential Property Survey, 2009; Detroit Works Long Term Planning Steering Team, 2012). Similarly, the area's 5-year average poverty rate between 2006 and 2010 was 36.1\% compared with 35.4\% citywide (Data Driven Detroit, 2012).

Second, however, the differences between Springwells Village and the rest of the city initially suggested that self-provisioning was likely especially prevalent in this neighborhood. For instance, in part due to the area's immigration history, formal education levels in Springwells Village were relatively low. About half of adult residents (53.4\%) had less than a high-school education compared with $23.2 \%$ citywide (Data 
Driven Detroit, 2012). Nevertheless, since poverty levels were unaffected, these statistics reinforced the popular belief that residents may have been especially active in informal labor markets. Additionally, unlike much of the city where vacant houses stood surrounded by empty fields, the vacant units in Springwells Village were densely intermixed with occupied homes, meaning that residents had easy access to vacant structures and, as proved more important, near neighbors immediately felt the spillover effects of worrisome reappropriations of those spaces. Moreover, in contrast to wealthier areas where self-provisioning was also likely but where people could afford to hire contractors to secure vacant houses and patrol the streets, many residents in Springwells Village had few options beyond their own personal labor. Lastly, rightly or wrongly, Latino households had a local reputation for using kinship labor to renovate their homes, giving many buildings in the neighborhood a distinctly 'southwest' feel, and reinforcing the perhaps racially biased assumption that informal activity was culturally encouraged in this community.

My research in Springwells Village began with a preliminary door-to-door survey completed in the spring of 2012. A team of two research assistants knocked on doors and spoke with 36 residents. Surveyors asked respondents about strategies they used to make housing affordable, safe and enjoyable over the preceding 5 years. I then personally completed an additional 61 interviews and participant observations in the late spring and early summer of 2012. The formal interviews (25 in all) included extended, semi-structured, tape-recorded interviews with residents, as well as with emergency responders, government representatives, nonprofit employees and local landlords. The participant observations (36 in all) involved attending resident brownbag lunches, community meetings, and neighborhood events and celebrations, as well as participating in resident-instigated service projects. These activities led to scores of short, impromptu, unrecorded interviews and casual conversations with residents as we worked, ate and rested together.

This mode of data collection had some limitations. First, this interviewee recruitment approach favored residents who were physically able and emotionally willing to attend public meetings and events. Second, while half of area households spoke Spanish at home, all interviews for this study were conducted in English. This English-speaking, community-joining subgroup was not representative of the entire neighborhood population. However, from all available indicators, it was representative of the subgroup of self-provisioning residents most engaged in extensive interventions intended to monitor and secure abandoned residential infrastructure. Moreover, a sustained effort to recruit interviewees with the help of a locally known language interpreter and bilingual information fliers did not significantly alter the composition of the respondents.

These surveys, interviews and participant observations yielded a wealth of primary source data. In what follows, residents' interventions are described in their own words whenever possible to give readers a sense of the motives and emotions involved. To protect confidentiality, no names or identifying features are included.

\section{Security concerns surrounding empty houses in southwest Detroit}

In the context of government withdrawal and market collapse, the residents I interviewed identified many risks that vacant houses posed to their neighbors in southwest Detroit.

One area of concern was the drug trade. Nearly every interviewee made unsolicited references to active or recently closed drug houses on their blocks. Although some dealers worked in legally occupied spaces, most interviewees believed that dealers used vacant houses to expand their trade, relocate after police raids or relocate after previous drug houses burned. For many interviewees, the presence of a drug house created unwanted foot traffic: 'Every 6 or 8 or 10 minutes, all day long, you have a parade of 
people coming to the house. The worst sort of people. And then the entire block and the people on the street are nervous'. Another respondent lamented that, ever since a vacant house nearby became a drug house, she could not leave her rain barrel in her backyard because 'all the crack hoes' walking down the alleyway 'will sit on it, shit on it, [and] get their AIDS infected feces in my mulch'. Many interviewees also worried that people buying drugs at one house would break into other empty properties to get high. For instance, several parents described refusing to let their kids play outside for months at a time to protect them from the used hypodermic needles they found lying on the ground and the figures they saw in the shadows of abandoned houses across the street.

Another pervasive concern was scrapping. According to a member of the Michigan House of Representatives who also lived in the neighborhood, three-quarters of the scrap metal buyers in the city were located in southwest Detroit and every resident I spoke with had direct experience with scrappers either stealing from their homes or dismantling nearby structures. Occupied houses were vulnerable but vacant houses were nearly defenseless and hotly targeted. In one acute but otherwise stereotypical account, a resident described an elderly couple who purchased the house next door and renovated it until the man suffered a heart attack and died. When his widow returned to the house two days later, "no cabinets were left on the walls, no fences left on the property, [and] no windows [were] left in their frames'. Other interviewees likewise described seeing people stealing copper piping, electrical wires, security bars, porch posts, rain gutters, window counterweights, driveway bricks, air conditioning units, roof shingles, furnace equipment, front doors and bathtubs. Alongside the value of the stolen material, scrapping also damaged buildings structurally, making it difficult for potential new occupants to move in. For instance, as one landlord explained, 'when people go into the houses to steal the copper piping', as occurred in one of his houses only hours after his tenants moved out, 'they leave the water on. It sprays everywhere. And the basement fills up. And then that water just sits there for years ... The scrapper might make $\$ 30$ or $\$ 40$ on the copper, and it cost me \$1,200 in repairs'. Many residents felt these activities had long-term negative impacts on the future viability of their neighborhood. In the words of one resident voicing her concerns at a community meeting, 'You can't get a community back if the house for sale costs $\$ 25,000$ and it costs $\$ 40,000$ just to get the heat on'.

A third area of concern was fire. During a string of interviews and a ride along with the neighborhood fire department, the firemen told me they combated between 30 and 40 house fires in a typical month in their eight-by-ten square block area. They estimated that $90 \%$ of the fires started in vacant houses and, about half the time, they spread to one or more occupied structures nearby. They said nearly all of these fires were the result of arson: 'Ninety-nine percent of the time, its deliberately set, either for demolition purposes just to get [the building] torn down, or [for] insurance purposes, or [it's] just arsonists who like to see fire'. For residents, fire was especially worrisome because many people in that neighborhood did not have homeowners insurance, either because they felt they could not afford it or because the physical conditions on their block rendered them ineligible for it. As such, many households lacked the financial resources that could help them rebuild after a fire. Moreover, since vacant houses often burned many times before burning to the ground, the threat to neighbors was longstanding.

Despite these concerns, interviewees often said that moving out of the neighborhood was not an option. Some residents lived in houses they had inherited mortgage free or in houses they had bought for cash or already paid off. Some people felt limited by their age, health status or seasonal employment patterns, which restricted their households' available cash flow. Some residents wanted to leave but felt they had to wait until their property values rose or their employment situation improved. Other residents wanted to stay, either because they valued the social support networks they had cultivated in the area or because they were ideologically committed to preventing further neighborhood depopulation and disinvestment. For these residents, the question was, what could they do about the vacant house issues until, as many hoped would happen, new people moved in or expanded city services became available? 
In theory, in other neoliberal urban spaces, a few possible solutions could help. One option that residents discussed was explicitly carceral, hinging on the arrest of drug dealers, scrappers and arsonists. Many interviewees described assisting police in these endeavors. Residents promptly reported crimes while they were underway, gave police license plate information about the suspects, supplied police with printed photos of suspicious activities and occasionally physically detained suspects for up to 45 minutes while waiting for the police to arrive. In one especially humorous account, a government official living in the neighborhood described filling her car with pajama-clad neighbors in the middle of the night and following suspected scrappers through the streets to track their movements and identify their home addresses. However, with city services understaffed and underfunded, residents and emergency responders alike described feeling that worrisome activities routinely occurred in broad daylight and with virtual impunity. As they told it, raided drug houses often reopened mere hours after a raid, police often refused to respond to complaints about scrappers because other violent crimes needed their attention and fewer than $2 \%$ of arson cases were ever prosecuted.

A second possible solution interviewees discussed was for municipal officials to hold private property owners accountable for keeping their buildings secure against potential criminal activity. However, my conversations with residents, as well as with officials at the municipal Department of Administrative Hearings responsible for overseeing code violation cases, revealed many shortfalls with this approach as well. Absentee owners were hard to find, many houses had nonmarketable titles and many people had walked away from their property on purpose hoping the city would confiscate it. One resident, for instance, showed me four city citations stapled to the front door of a severely dilapidated vacant house next to her: 'I called the owner to tell him he had citations and asked him to come out and clean the property up. And he just laughed at me'. Interviewees had strong opinions about the source of these dismissive attitudes. In the words of a nonprofit employee working on area housing issues: 'A lot of times, [the owners] inherited the house. They don't really live there or want to maintain it. They can't sell it, even for a few grand. And so they walk away and let it go through tax foreclosure to get taken off their hands'. As another interviewee put it: 'For landlords letting their buildings go vacant, the houses have asbestos in them. And it is expensive to remove it. So they let it burn so they won't have to remove it and can just bulldoze it all over'. Similarly, a local businessman showed me photos he had taken of houses with back doors left wide open and with full bottles of lighter fluid sitting just inside the threshold, a condition he characterized as an owner's invitation to bored neighborhood teenagers to set the buildings on fire. Moreover, the city already owned many of the so-called problem properties and, according to the local police sergeant who lived in the neighborhood and echoed by a hearing officer overseeing city-issued citation cases, 'As a matter of policy, the city doesn't ticket itself for code violations'.

\section{Resident-instigated self-provisioning security strategies}

With no expectation that a government solution - let alone a market revival - was forthcoming, many interviewees reported feeling the pressure to act on their own to keep their block safe and governable. Controlling access to and use of residential infrastructure was important in these endeavors. The residents I interviewed devised ways to use their manual labor to partially recreate the landscape they believed city governments ought to provide but that, following government withdrawal, they felt they needed to instigate instead. In this attempt, residents tested many working solutions and stopgap measures with varying levels of success. Five especially prominent strategies included masking houses' vacant status, marking empty structures as claimed and protected, enlivening empty spaces to demonstrate community strength, fortifying houses against potential occupancy and sabotaging buildings to eliminate their sheltering capabilities. 
The first strategy, masking houses' vacant status, was an exercise in disguise. The goal was to use objects and staging to create the illusion that a vacant house was actually occupied. For instance, residents on one block used this approach to secure an empty house after a bank foreclosure. According to the house's subsequent owner: 'Banks take everything out of the house leaving it looking obviously empty ... The neighbors put window shades back on the house so it wouldn't look so obviously abandoned'. The more props used, the more convincing the masking became. As one landlord explained:

A month ago while talking to neighbors ... I learned ... the hidden reality that six nearby homes on the same block, which appeared to be occupied, were actually abandoned ... Neighbors try to mask [that] reality by continuing to cut the lawns, place furniture on the porches, and [place] kids toys in the front yards.

Local community groups encouraged masking by circulating fliers that urged residents to collect mail, mow grass, pull weeds and put potted plants on porches 'to make the house look lived in'. According to interviewees, most residents felt this type of stage dressing, in the right circumstances, could help a vacant house blend in with the occupied ones around it, making it harder for passersby to identify it as a potential site for scrapping, drug dealing or arson.

Some telltale signs of vacancy were hard to disguise, such as missing electrical meters or missing doors and windows. In those instances, residents often tried marking the property to indicate that, although the house might be vacant, it was nonetheless a claimed space. Neighbors sometimes used literal signs pounded into the ground or painted onto building facades. Signs like 'No Dumping', 'You're On Camera', or 'This House is Being Watched' were common. The people hanging these signs believed they were distinguishing those houses from other vacancies by signaling that someone was nearby, interested and watching. 'Even though we know there's no cameras there or nothing like that ... just by putting that sign up saying you're on camera, [people will] think twice' before engaging in illicit behavior on that property. Another set of signs posted on dozens of vacant houses read, 'Save our Neighborhood. Need Help on your Block. Contact [Local Business Name, Phone Number]'. These signs encouraged neighbors who were reluctant or unable to intervene on their own to notify other residents or landlords willing to take action on their behalf.

Alongside these literal signs marking houses under surveillance, neighbors also used landscape cues to deter unwanted drug, scrapping and arson activities. One woman, for instance, saw the house next to her go vacant, then become a drug house and then go vacant again. After the drug dealers left, even though the house's damaged façade rendered it visibly uninhabited, she began cutting the grass, putting out potted plants and planting rose bushes that she 'got cheap at an end of season sale [for] \$2 a bush'. In another instance, a parent with young children regularly woke early to mow the lawn in front of several vacant houses on his block before leaving for work so his wife would feel comfortable letting their children play outside during the day. In this neighborhood, this type of active landscape maintenance was widely recognized among interviewees as a signal that someone had assumed stewardship of the building, reinforcing the structure's status as a private space. Neighbors often coordinated with each other in these efforts. For instance, one woman cut the grass on the west side of a vacant house while the neighbor on the other side mowed the eastern half. One man cut the front lawns of two vacant houses and his backyard neighbors cut the rear lawns. An elderly man mowing around five vacant houses eventually recruited a younger neighbor to take over one of the larger properties in his stead. In addition, when residents traveled or were ill, they asked neighbors to mow around 'their' vacant houses for them.

If these signs of care were ignored, people sometimes used a third strategy of enlivening the house by using human bodies, rather than window shades and lawn care, to signal that an empty structure was nonetheless not abandoned. Some enlivening tactics were indirect, intended to encourage more neighbors to adopt vacant houses to reduce the 
number of seemingly unclaimed spaces in the neighborhood. For instance, one block club organized a recurring 'Hour of Power' when residents met to mow, weed and collect trash around vacant houses in different nearby locations every week. Participants occasionally borrowed equipment from a local community group but most of the time participants used their own resources and brought mowers, loppers, edgers, rakes, shovels, garbage bags and fuel from home. As I observed, when initially setting up the Hour of Power, block club members spent considerable time debating when to meet because they wanted their neighbors who were not attending community meetings to see them doing the work. 'It will inspire residents to take action [and] to come out and work themselves alongside us'. The group eventually settled on a weekday evening because that was when they believed most people would be home to see them. They also decided to wear matching neon orange shirts to attract even more attention in the hope that neighbors witnessing their example would complete the landscape chores in the future.

Enlivening empty houses also assumed explicitly confrontational forms. One interviewee, for instance, said she was having trouble with someone dumping garbage in the backyard of a vacant house behind her: 'So I took my gun and went outside so the guy could see the gun under my coat. And I asked him to pack up his trash and take it away and not to come back. And he picked up his trash and left. Mattresses, I think it was'. Another resident reacted to someone stealing electrical wires from the vacant four-unit apartment building behind her house: 'I ran outside and pounded on their car window [and] yelled and cursed and them'. A third, elderly woman who had difficulty walking likewise described confronting scrappers next door. Although she was physically unable to chase anyone, she said, 'I'll open the window and shout at them, "You better turn tail and run because I'm going for my gun!"' Residents used these physical and verbal cues to assert control over nearby property within eyeshot of their own homes.

In instances where masking, marking and enlivening vacant property proved impractical or ineffective at preventing drug dealing, scrapping and arson, residents often resorted to a fourth strategy of physically fortifying housing units against potential occupancy. The most conventional form of fortification involved boarding up doors and windows. In one especially poignant account, a resident described her decision to board a vacant house nearby to keep it from becoming an intermittent drug house after a related drug house nearby was raided and burned. One weekday morning, after the drug dealers had left for the day, she set out to recruit help:

The men on the block were shamed. Like, 'Hey, other people have already dealt with the original crack house. You guys all have children. What's up? By the way, we'll be picking up a couple cases of beer and starting a BBQ for anybody that wants to do some community service today'.

Her neighbors responded. They removed the entry steps from the building and used scrapped lumber from another vacant house to barricade the doors and windows. 'Everything was boarded from the interior. I think there's probably three-hundred-andsome three-inch wood screws at every orifice there is'. In another example illustrating a more systematic, capital-intensive fortification project, a businessman and landlord with property interests on several blocks began boarding vacant structures in 2011 . He bought plywood, rented specialized equipment, and paid workers out of pocket to do the work: 'We effectively trespass and vandalize these abandoned properties regularly. To date we have secured over 60 homes and two commercial buildings'. Neighborhood residents responded warmly to his efforts, inundating him with requests to board more properties and showering him with community awards and accolades. Employees with a local community group especially praised the quality of his workmanship because his crew boarded the upper stories and hard-to-reach places that their organization left open for liability reasons.

Some interviewees who were unable or unwilling to manage the cost of purchasing boards or the work of climbing ladders nevertheless devised ways to fortify structures 
using found materials instead. In one example, an interviewee who was angry that scrappers used the backyard of a vacant house to access an adjoining property said:

We wound up just felling all the weed trees from the alley in the lot just to slow the traffic down. It's like, you will have to go out the front of the property in front of all the neighbors with what you steal. You're not cutting in and out of an alley at night. And if you do, you're going to have to trip over all these trees, and good luck [laughter].

In another instance, after cleaning up a rat-infested house next to an elementary school playground, volunteers used tree trunks to create blockades around the house so people could no longer back trucks up to the door to remove scrap material or dump unwanted debris. In a third case, after a bank-owned house had been renovated and then immediately scrapped three times in four months, the next door neighbor responded by building his dog house in the backyard of the vacant house so his dog would prevent people from entering the property a fourth time. Neighbors also used found materials to create 'booby traps' around vacant houses. One woman, for instance, placed bricks on either side of a gate so that it would scrape across the ground and make noise if someone opened it. Next, she laid a wood rail across the walkway to trip the person in the dark. Then, at a pinch point in the walkway, she placed a garbage can filled with bricks that the person had to drag aside to pass by, which again made a distinctive sound: 'So you can still get in, but we're not going to make it easy for you, and we're going to know about it'.

Fortifying a house also involved clearing the landscape rather than just barricading it. For instance, after what one interviewee described as a mini crime wave on her block, she recruited neighbors to help remove debris, trim large tree branches, and remove overgrown shrubs from the fronts of vacant houses: 'It made a difference. We had lots of problems before, and now there are very few. There's nowhere to hide'. Around the same time, a landlord experimented with Tattle Tale security systems commonly used at construction sites. He put motion detectors in empty houses and put the alarms in occupied houses farther away to alert the neighbors when someone entered a property that was supposed to be vacant. His long-term goal was to connect these alarms to email blasts containing address information so concerned neighbors could quickly congregate as a group to chase people away.

In instances where these strategies proved insufficient to prevent people from breaking into unoccupied houses, neighbors occasionally tried a fifth strategy, sabotage, which again took many forms. In the more benign cases, neighbors described refusing to take over the landscape chores and intentionally ignoring people who were damaging the structure. 'The worse [the house] looks, the more tickets [the owner] will get, and the sooner it will get chopped down'. Other residents piled yard trimmings around vacant houses so owner citations would pile up. A few interviewees reported using sledgehammers to damage the interiors of empty houses, hoping to make the rooms so uninviting that drug dealers would not want to be there. A handful of residents bought vacant houses next door just to dismantle them either by themselves or in groups and in one instance using an online fundraising campaign.

In rare but extreme cases, neighbors hinted to me that they occasionally set fire to houses to keep drug dealers away. A conversation I observed among a group of residents meeting for lunch shed light on this practice. One woman commented that she bought a vacant house next to her just to control it: 'If I hadn't got it, I would have wanted to see it burn rather than see it become a crack house'. Another woman responded with the story of a house next door that had become a drug house, 'and then mysteriously', she said with a wink, 'a few months later, the house burnt down'. She then said she would rather have set fire to the house herself than live with drug dealers next door. A third resident added that, sometimes when she called the police to complain about a drug house down the street, 'the hotline operator has said, "Are you sure you've got the right number? Are you sure you don't want the number for the Fire Department instead?" Hint, hint'. 
Similarly, in my conversations with local fire fighters, they reported that residents occasionally urged them to slow down when quelling some flames: 'Some of the neighbors . . . they get kind of irate. If it's a crack house, they're like, "let that M-F-er burn", or whatever'.

When pressed, only one interviewee provided specific details. According to her, in response to a persistent drug house that she believed corrupt city officials were protecting, she and two neighbors told an undercover police officer, 'You can leave. Go back and tell your boss that the neighbors are going to take care of this'. They then used a military-grade plastic explosive placed on the ground floor in the center of the house to set the building on fire. That way, in their reckoning, the fire department would have time to extinguish the fire before the flames spread to their own houses but not before the vacant structure would be fully destroyed and collapse in on itself.

To be clear, all the evidence suggests that these 'defensive' fires were primarily responses to drug activity and that they comprised an extremely small percentage of the total house fires occurring in the neighborhood. The goal of this type of arson, like the other mechanisms of sabotage interviewees described, was to eradicate the house on the neighbors' terms to permanently eliminate the possibility that someone else might seize the space as a drug house or arson target while they were asleep and vulnerable in the night.

In sum, when asked why they participated in masking, marking, enlivening, fortifying, and sabotaging vacant properties, interviewees invoked the limited government capacity and the failure of housing markets to manage neighborhood spaces and to protect area residents from what they saw as environmental blight and personal danger. In a typical reply, one resident said he behaved as he did because that was 'what's necessary to make sure the entire street doesn't go to shit in an instant'. Another resident said, 'No one will help us. We have to help ourselves'. In the words of a third interviewee, 'You have to take matters into your own hands here. 'Cause if not, if you wait, then you wait, and wait, and wait. You're going to end up frustrated and it's probably going to not get done'. Residents recognized that the effects of their actions were often short lived and at times ethically fraught. Interviewees also felt it was unjust that property owners and city officials were not adequately addressing these problems. Even so, masking, marking, enlivening, fortifying and sabotaging vacant structures were strategies that concerned neighbors could try when they came face to face with citywide disinvestment in the form of abandoned houses next door. These strategies provided immediate, short-term protection when nothing else was working.

\section{Discussion: evaluating guerilla-style defensive architecture in a neoliberal city of disinvestment}

At their most basic level, these practices of physically altering vacant housing functioned as self-provisioning practices with residents using their manual labor to improve their private living spaces without going through state or market intermediaries. People performed this work primarily to circumvent unreliable service providers and to help residents feel safe and comfortable in their homes. These practices bolstered residents' sense of control over infrastructure that they felt was no longer being effectively managed. These actions shaped physical environments in ways that created checks on other people's behavior in a context where government contraction was not followed by public-private investments in securing the houses going empty or protecting the people living nearby. Therefore, many residents devised their own guerilla-style spatial interventions to attempt to do this work instead.

In assessing the long-term evolution and utility of these practices, several factors must be weighed. First, residents often selected one strategy over another depending on the condition and history of the house in question. For recently vacated structures or for 
buildings with little damage visible from the street, residents believed that masking and marking structures could shield them from potential (mis)appropriation. However, as the exterior building quality deteriorated, illusions of occupancy were harder to maintain. Moreover, interviewees often believed that buildings with visible damage from previous scrapping or fire were more likely to be seen as 'fair game' and become targets of repeat destructive activities. In those instances, fortification and accelerated demolition took priority. When considering sabotage, however, interviewees only reported using the extreme tactics of sledgehammers and fires in cases of ongoing drug activity or anticipated expansions in the local drug trade.

In terms of impact, each of these strategies showed success on a case-by-case basis. Interviewees expressed greater confidence in masks and boards than in other defensive techniques. Strategies of enlivening buildings with human activity yielded the most ephemeral benefits, but they were nevertheless the most effective option at the exact moment when neighbors saw strangers entering empty properties. However, if the ultimate goal was either to preserve buildings until new occupants moved in or to elevate a building's status on prioritized municipal demolition lists, these strategies often failed. Occasionally new residents moved in or city-contracted bulldozers arrived. More often, in the eyes of interviewees, empty structures that sustained damage remained empty and continued to decay, albeit perhaps at a slower rate than their undefended counterparts. Even so, slowing decay offered neighbors more peaceful nights in the short term, time to make relocation plans or symbolic victories bolstering their resolve to stay and invest in the neighborhood.

Another factor involved the profile of residents engaged in these types of practices. Homeowners appeared more likely to take action than renters, although firm data on this point were not collected. Older residents and especially able-bodied retirees appeared especially likely to collaborate on evidence-of-care-type tasks and they also appeared more likely to take action on sites farther from their homes. In contrast, households with young children at home were more likely to tackle similar jobs independently and at unpredictable hours of the day depending on their work and family time constraints. Younger interviewees were more likely to describe the desire to spend time outside as a motivating factor. Older residents with health issues were an exception, both in that they were much less likely to attempt physical landscape transformations alone and in that younger residents cited the perceived vulnerability of their infirm neighbors as reasons they expanded their activities geographically farther from home than they would have otherwise.

In terms of ethnicity, in this heavily Latino neighborhood in an otherwise predominantly African American city, interviewees expressed a belief that racism was a central factor explaining citywide disinvestment and that ethnicity influenced the self-provisioning work residents performed on their personal homes. As evidence, interviewees pointed to the large number of rebuilt front porches, the use of stone and brick instead of wood in home-improvement projects and the presence of vegetables like chocolate peppers and pineapple tomatillos in backyard gardens. These stereotypical elements of Latino culture were adaptations residents made to their immediate living environments for cultural purposes. However, I found little evidence that ethnicity had a significant effect on the landscape-based security strategies residents deployed around vacant housing. Interviewees engaging in these activities rarely described feeling long-term emotional or financial connections to the places other people left empty. They spent little time inside those structures and tried to secure them with minimal physical and economic investment. Moreover, many interviewees referred to similar practices they observed in other predominantly African American areas of Detroit, but no interviewees made references to Latino culture or previous experiences rooted in Latin America or the American southwest when describing the physical labor they performed on properties they did not occupy.

My own preliminary observations likewise suggested that the security-oriented strategies underway in southwest Detroit resonated with those emerging citywide. 
Wealthier areas sometimes hired people to do the work or placed a greater emphasis on masking vacancy to protect property values, and harder-hit areas sometimes pursued demolition strategies more strenuously. However, these differences appeared to be the result of differences in the extent of vacancy rates and the amount of resources available rather than differences stemming from ethnic composition. It appeared, then, that while ethnicity influenced self-provisioning on residents' own homes, it had little effect on the range of strategies used to keep empty structures from being scrapped, burned or used as drug houses.

In summarizing assessments of efficacy, in some households, interviewees described self-provisioning as instrumental in creating a safer home environment. However, these tactics were not practical for every household, they were not effective in every circumstance, and they proved markedly insufficient to fully replicate the municipal systems of land management and social control to which interviewees believed they ought to be entitled. Respondents stressed that the labor was time consuming, physically exhausting and emotionally stressful. The benefits were fleeting and easily reversed. Often only a few people on a block were responsible for most of the securityoriented interventions in their area. These activities also did not effectively supplement incomes or reverse the prolonged lack of municipal services available in the community.

In response to these shortcomings, some larger philanthropic entities have started funneling resources towards these practices to scale up their prevalence. For example, in 2008, the Detroit-based nonprofit Michigan Community Resources began awarding mini grants of between $\$ 1,000$ and $\$ 5,000$ to small community groups to cover expenses such as the material costs of boarding abandoned properties, planting flowers to disguise vacancy, installing motion detectors at building entrances, installing concrete barricades in front of abandoned driveways and mowing around empty houses and lots. Similarly, in 2010, the nonprofit organization released a manual offering residents advice on how to work more systematically in these endeavors, as well as on how to collaborate with police officers and municipal employees in their efforts (Detroit Vacant Property Campaign, 2010 [2008]). Despite the temptation to read the situation as an example of intentional government campaigns to offload responsibilities onto charities and households, in 2012 in southwest Detroit, these practices functioned primarily as an organic, grassroots response to government contraction rather than as overtly solicited entreaties to take on the work governments no longer provided. Even so, these philanthropic initiatives reverberated with neoliberal ideologies of private urban governance in that they pointed the way towards potential public-private partnerships with householders and charities performing the infrastructural management work that governments used to perform and that market actors deemed unprofitable but that were nonetheless necessary to daily life.

Measures of efficacy aside, these guerilla-style defensive architecture practices raised many ethical dilemmas which residents negotiated with varying levels of explicitness and savvy. One issue had to do with exclusion. These practices were explicitly intended to keep 'unwanted' people away, which introduced the problematic notion of a community standard of desirability. Interviewees freely acknowledged - and at times adamantly insisted - that many people involved in drug dealing, scrapping and to a lesser extent arson also lived on their blocks or in the neighborhood. In many instances, while one resident worked to preserve a house, another neighbor across the street was working to dismantle it. These contradictions suggested the lack of a commonly agreed on standard as to what constituted deviant behavior and what counted as having the good sense to make use of resources otherwise headed for the landfill. Moreover, for most interviewees, the only people who could legitimately make use of empty spaces were the lawful owners or tenants. In a few exceptions, residents expressed openness to the idea of a 'good' squatter earning their keep by taking care of the property but, in practice, no interviewees described giving 'trespassers' much opportunity to demonstrate their worthiness on this score. 
A related issue arose from the potential dangers of leaving individual residents to enforce neighborhood standards without sufficient agreement on how that action ought to be accomplished. Without publically accountable oversight, on the spectrum ranging from planting rosebushes to boarding doors and windows to setting houses on fire, how far was too far? Concerns were especially heated in instances of confrontation when some interviewees expressed concerns about potential vigilante violence. Interviewee comments suggested that there was only a loose consensus among a handful of residents on this issue. Moreover, although many respondents voiced apprehension about the property destruction around them, those same people still expressed a belief in a tipping point where managed destruction instigated on their own terms was their best hope of improving their situation. However, even when residents collectively agreed that a structure could hit some point beyond which it was unsalvageable, the exact tipping point remained ill defined and the preferred demolition methods remained contentious.

A third dilemma arose from questions of whether residents could pursue this work without giving up hope of structural reform. Many interviewees worried that, if they performed the work of managing infrastructure, city officials might use their efforts as an excuse to abandon the municipality's responsibility to perform that work altogether. Therefore, the role of the self-provisioning householder was a grudging and contradictory one. Residents expected that nothing would improve unless they did the work themselves, but taking action seemed to imply consent with the neoliberal system that had left their government and market unaccountable for the ongoing reproduction of poverty disproportionately borne by their community. If anything, rather than constituting a romantic image of the urban homesteader, the length residents went to underscore the severity of the problems they faced and the desperation they felt as institutional mechanisms of social control repeatedly failed them. These selfprovisioning practices, while helpful in the short term, showed little likelihood that they would bring significant new resources into the neighborhood or counteract the regional and global systems of racial and financial abandonment reproducing the area's poverty and blight.

Despite the unevenness of defensive landscaping practices and the many unresolved concerns they generated, these accounts from southwest Detroit illustrated a poignant new mode of daily life in a neoliberal space of disinvestment. This article has explored neoliberalism as it related to Detroit, the new roles residents were expected to play under austerity regimes and the place-making implications of their actions in a city of disinvestment. Householders described feeling pressure to tackle issues that real estate markets and city governments once oversaw but that residents now felt they were left to manage alone. In this instance, with no government or market solution in sight, residents pursued guerilla-style tactics on their own not to create provisionally public spaces but rather to reprivatize formerly private spaces that other people were treating as publicly claimable. Their actions, when aggregated, have begun to lay the foundation for a grassroots system of land control and social regulation. These security practices constituted one aspect of self-provisioning that occurred alongside backyard gardens and do-it-yourself home repairs. However, in the era of neoliberal austerity, self-provisioning went beyond people's efforts to circumvent markets. Instead, self-provisioning was also, and critically, a security strategy that residents used to govern infrastructure and restrict its potential reappropriation in their living environment.

Given that disinvestment and inequality have become intrinsic characteristics of the current neoliberal urban order around the world, developing a more thorough understanding of the modes, contradictions and dilemmas associated with residents' new roles in service provisioning may be especially important if issues of social justice and quality of life are to be meaningfully addressed within the narrow legal and fiscal constraints that many people now inhabit. These defensive architecture practices generated many localized benefits and, on a case-by-case basis, they were successful as methods to negotiate vulnerability, even if just by slowing decline or enhancing sensibilities of comfort and safety. However, this bootstrap urbanism left regional and 
global disinvestment - the structures producing vulnerability - unchecked. Moreover, even at their most successful, these practices were laden with conflict and ethical dilemmas, which existing citywide laws intended to mediate disputes among neighbors were ill equipped to resolve. Ultimately, these self-instigated urban practices were not a model of urban governance, but rather they reflect the reality of an emerging urban condition in need of more comprehensive reforms.

Kimberley Kinder (kkinder@umich.edu), Michigan Society of Fellows, Urban and Regional Planning, University of Michigan, 0540 Rackham Building, 915 E. Washington Street, Ann Arbor, Ml 48109-1070, USA.

\section{References}

Adams, V. (2013) Markets of sorrow, labors of faith: New Orleans in the wake of Katrina. Duke University Press, Durham, NC.

Associated Press (2013) Detroit files for largest municipal bankruptcy in US history. Fox News 18 July [WWW document]. URL http://www.foxnews.com/ politics/2013/07/18/detroit-files-for-largest -municipal-bankruptcy-in-us-history/ \#ixzz2f5Wf4HLf (accessed 16 September 2013).

Austin, D. and S. Doerr (2010) Lost Detroit: stories behind the motor city's majestic ruins. The History Press, Charleston.

Bakker, K.J. (2003) An uncooperative commodity: privatizing water in England and Wales. Oxford University Press, Oxford.

Beauregard, R.A. (2006) When America became suburban. University of Minnesota Press, Minneapolis.

Berlant, L.G. (2011) Cruel optimism. Duke University Press, Durham, NC.

Binelli, M. (2012) Detroit city is the place to be: the afterlife of an American metropolis. Metropolitan Books, New York.

Chase, J., M. Crawford and J. Kaliski (eds.) (2008) Everyday urbanism: expanded. Monacelli Press, New York.

CNBC (2013) Detroit becomes largest US city to file for bankruptcy. NBC News 18 July [WWW document]. URL http:// www.nbcnews.com/business/detroit -becomes-largest-us-city-file-bankruptcy -6C10678946 (accessed 16 September 2013).

Data Driven Detroit (2012) 2012 Data profile: Springwells Village. Detroit Local Initiatives Support Corporation, Detroit [WWW document]. URL http:// datadrivendetroit.org/projects/lisc-bsc/ springwells-village/ (accessed 12 December 2012).

Davidson, K. (2012) Detroit has tons of vacant land. But forty square miles? Changing Gears 18 April. Michigan Radio, Ann Arbor [WWW document]. URL www.changinggears.info (accessed 8 January 2013).

Davis, M. (1992) Fortress Los Angeles: the militarization of urban space. In M. Sorkin (ed.), Variations of a theme park: the new American city and the end of public space, Hill and Wang, New York.

Detroit Residential Property Survey (2009). Data Driven Detroit [WWW document]. URL http://datadrivendetroit.org/ (accessed 17 January 2013).

Detroit Vacant Property Campaign (2010 [2008]) Vacant property toolbox. Second edition. Michigan Community Resources, Detroit (available from Michigan Community Resources, 615 Griswold Street, Suite 1400; Detroit, MI 48226, USA).

Detroit Works Long Term Planning Steering Team (2012) Detroit future city: Detroit strategic framework plan, December. Detroit Works Project, Detroit [WWW document]. URL http:// detroitworksproject.com/ (accessed 25 January 2013).

Dillard, A.D. (2007) Faith in the city: preaching radical social change in Detroit. University of Michigan Press, Ann Arbor.

Dolhinow, R. (2010) A jumble of needs: women's activism and neoliberalism in the colonias of the southwest. University of Minnesota Press, Minneapolis.

Gallagher, J. (2010). Reimagining Detroit: opportunities for redefining an American city. Wayne State University Press, Detroit. 
Georgakas, D., and M. Surkin (1998) Detroit, I do mind dying. South End Press, Cambridge, MA.

Graham, S. (2011) Cities under siege: the new military urbanism. Verso Books, London.

Graham, S. and S. Marvin (2001) Splintering urbanism, networked infrastructures, technological mobilities and the urban condition. Taylor and Francis, London.

Hackworth, J.R. (2007) The neoliberal city: governance, ideology, and development in American urbanism. Cornell University Press, Ithaca.

Harvey, D. (1989a) From managerialism to entrepreneurialism: the transformation in urban governance in late capitalism. Geografiska Annaler. Series B. Human Geography 71.1, 3-17.

Harvey, D. (1989b) The condition of postmodernity: an enquiry into the origins of cultural change. Blackwell, Oxford.

Harvey, D. (2001[1992]) A view from Federal Hill. In D. Harvey (ed.), Spaces of capital: towards a critical geography, Routledge, New York.

Herbert, S. (2005) The trapdoor of community. Annals of the Association of American Geographers 95.4, 850-65.

Herscher, A. (2012) The unreal estate guide to Detroit. University of Michigan Press, Ann Arbor.

Hou, J. (ed.) (2010) Insurgent public space: guerrilla urbanism and the remaking of contemporary cities. Routledge, New York.

LeDuff, C. (2013) Detroit: an American autopsy. Penguin Press, New York.
Maher, K., B. White and V. Bauerlein (2012) Hard times spread for cities. The Wall Street Journal 10 August [WWW document]. URL http://online.wsj.com/ news/articles/SB10000872396390 444900304577581162498135058 (accessed 21 November 2013).

Mitchell, D. (2003) The right to the city: social justice and the fight for public space. Guilford Press, New York.

Newman, O. (1973) Defensible space: crime prevention through urban design. Collier Books, New York.

Pattillo, M. (2008) Black on the block: the politics of race and class in the city. University of Chicago Press, Chicago.

Peck, J. and A. Tickell (2002) Neoliberalizing space. Antipode 34.3, 380-404.

Plumer, B. (2013). Detroit isn't alone. Washington Post 18 July [WWW document]. URL http://www .washingtonpost.com/blogs/wonkblog/wp/ 2013/07/18/detroit-isnt-alone-the-u -s-cities-that-have-gone-bankrupt-in -one-map/ (accessed 21 November 2013).

Sugrue, T.J. (1996) The origins of the urban crisis: race and inequality in postwar Detroit. Princeton University Press, Princeton.

Thomas, J.M. (1997) Redevelopment and race: planning a finer city in postwar Detroit. Johns Hopkins University Press, Baltimore.

Thompson, H.A. (2001) Whose Detroit? Politics, labor, and race in a modern American city. Cornell University Press, Ithaca. 